\title{
Factors Influencing the Acquisition of Employability Skills by Students of Selected Technical Secondary School in Malaysia
}

\author{
Jovinia Dania ${ }^{1}, \mathrm{Ab}$ Rahim Bakar $^{1} \&$ Shamsiah Mohamed ${ }^{1}$ \\ ${ }^{1}$ Faculty of Educational Studies, Universiti Putra Malaysia, Malaysia \\ Correspondence: Ab Rahim Bakar, Faculty of Educational Studies, Universiti Putra Malaysia, Malaysia. E-mail: \\ abrahimbakar@yahoo.com
}

Received: November 22, 2013

Accepted: December 26, 2013 Online Published: January 24, 2014

doi: $10.5539 /$ ies.v7n2p117

URL: http://dx.doi.org/10.5539/ies.v7n2p117

\begin{abstract}
The main purpose of the study was to assess the acquisition of employability skills by vocational students in Malaysia. A total of 214 students participated in the study. We used the SCANS instrument to assess vocational students' employability skills. The overall mean of vocational secondary students' employability skills was 3.81 $(\mathrm{SD}=0.34)$. Students' employability skills were found to be correlated with gender $\left(\mathrm{r}_{\mathrm{pb}}=-.172, p=.012\right)$, industrial training $\left(\mathrm{r}_{\mathrm{pb}}=.137, p=.046\right)$, involvement in extracurricular activities $(\mathrm{r}=.177, p=.010)$, participation in career development activities $(\mathrm{r}=.218, p=.001)$ and self-concept $(\mathrm{r}=.429, p=.000)$. We used a step-wise multiple regression to determine the variables that best predict students' acquisition of employability skills. We found that three variables (self-concept, participation in career development activities, and industrial training) explained $23.1 \%$ of the total variance in the acquisition of employability skills, with self-concept being the main predictor $(\beta=0.39)$, followed by participation in career development activities $(\beta=0.29)$, and industrial training $(\beta=0.19)$.
\end{abstract}

Keyword: technical and vocational education, employability skills, Malaysian secondary school students

\section{Introduction}

The development of information technology shifts in the types and nature of available jobs, and changes in the world economy require people to adapt quickly to the needs of the world of work. Thus, governments of many nations have striven to educate and train the human capital to address these challenges. This includes Malaysia, a developing nation that aspires to be recognized as an industrialized and to create a high-income society, raising per capita income levels from USD \$6,700 in 2009 to beyond USD \$15,000 by 2020 (Pemandu, 2012). In order to achieve those goals, the country must ensure a large pool of high skilled workers by increasing enrollment in technical and vocational education programs. Various ministries, government agencies, and private sector actors are work toward ensuring Malaysia has the 3 million high-skilled workers needed by the year 2020. One of the ministries involved in this process is the Ministry of Education through the Technical and Vocational Education Division.

\section{Employment and School Leavers}

In 2009, 47.7\% of Malaysia's the labor force was between 15 to 24 years of age. Most of these workers (64.1\%) were secondary school graduates (Department of Statistics, 2009). As reported in the country's most recent development plan, many youths (approximately 100,000) enter the job market immediately after completing 11 years of schooling, with only a basic diploma or certificate of education, and lacking any true skills (Government of Malaysia, 2010: The $10^{\text {th }}$ Malaysia Plan). This may negatively impact workers in terms of lowering their prospects for career advancement and may lead workers to change jobs frequently (Smith, Dalton, \& Dolheguy, 2004).

In 2009, the country's unemployment rate was 3.7\% and this has declined a bit as of late, with $3.3 \%$ in $2010,3.1 \%$ in 2011, and 3.0\% in April of 2012 (EPU, 2012-The Malaysian Economy in figures). Worldwide, unemployment among youths is three times higher than the unemployment among adults (ILO, 2010). Fresh from school but with no work experience and a lack of employability skills, they often find themselves unable to compete for limited job opportunities. Slow economic growth, globalization, skills mismatch, and unrealistic aspirations among youth also contributed to the higher unemployment rate. Studies among Malaysian high school students 
have shown that their job and educational aspirations are inconsistent with their academic achievement. This is an issue not only in Malaysia, of course, but is illustrative of issues across the globe.

\section{Employability Skills}

In the new global economy, workers need more than technical knowledge and skills, which are often job-specific and not transferable. In addition to these skills, they must also have soft skills- "employability skills"-if they want to continue contributing to the growth and expansion of an industry or corporation. Employability skills are the skills, knowledge, understanding and personal attributes that enable a person to obtain employment, and to be successful and satisfied in their chosen career (Lorraine \& Sewell, 2007). Barnett (2006) explains that employability skills enable people to obtain suitable employment and at the same time develop their careers during social and technological change.

Employability skills are necessary across all areas and types of jobs. Alston, Cromartie, Wakefield, and English (2009) studied their importance in the agricultural sector in the U.S, suggesting that interpersonal communication skills, for example, are essential to the technical knowledge and abilities of university graduates in the industry.

In addition, these skills are important to employers and employees in developing a company. Technological developments require manufacturers to meet consumers' demands for cheaper and higher quality goods. Therefore, to remain competitive, front-line workers need to know and apply the technology to solve problems, communicate effectively, work in teams, and assume responsibility for quality and productivity. Hence, tertiary education institutions should provide a curriculum that emphasizes the development of soft skills.

Rabey (2008) found that there is room for improvement in the way that secondary schools prepare their students for the workforce, and suggested placing more emphasis on teaching organizational structure and interactions, money management and market dominance, communication, teamwork, and goal setting. These can be boiled down to three important areas: life skills, work skills, and knowledge of the workplace.

At the high school level, adolescents between the ages of 16 and 17 years can assess and explore personal interests and needs, particularly in relation to a future career. In psychology, this is the best time to give exposure to the youth about the career world. Sharing knowledge about careers will indirectly strengthen adolescents' desire to continue their studies in technical and vocational schools.

\section{A Summary of Technical and Vocational Education in Malaysia}

The Technical and Vocational Education Division (TVED) of the Ministry of Education was established in Malaysia in 1964. It aims to develop technical and vocational education and improve the national education system. In 2002, academic schools (grade 9-10) began offering technical and vocational subjects as elective courses. In 2006, the division implementation competency-based education for vocational subjects using a modular system, and recently some technical and vocational schools have been improved and upgraded to vocational colleges. The aim of these efforts is to enable students to gain employment, start their own business, or pursue training at a higher level to meet the national needs in line with Vision 2020 (Mission 2020, 2006). To meet this objective TVED developed a vocational curriculum that features Tech Prep, combining two important elements of articulation and connectedness (Technical and Vocational Curriculum Division, 2007). Articulation provides access to allow students to either pursue their studies at higher levels or seek employment. Connectedness means that what they have learned in school has a relationship with the environment and the actual situation in the workplace. In this context, the elements of employability skills have been promoted through programs such as industrial attachment, school enterprise and traineeship programs (Ahmad-Tajudin, 2009).

Recently, the Ministry of Education Malaysia has upgraded some of the technical and vocational schools to college status, and as of 2013, there are 56 Vocational Colleges. Beginning in July of 2013, the ministry will collaborate with the Industrial Training Institutes, under the purview of Ministry of Human Resource, to jointly implement College Vocational programs at 11 Industrial Training Institutes. At the school level, the development and assessment of employability skills is assessed by Technical and Vocational Education and Training (TVET) (Maclean \& Ordonez, 2007).

\section{Objectives of the Study}

Given the new initiatives implemented by the Ministry of Education, we conducted this study to determine how the implementation of TVET in a selected technical school has helped students acquire employability skills. We also set out to determine the relationship between students' level of employability skills and selected factors, and to determine the predictors of students' employability acquisition.Thus, we set forth the following null 
hypotheses:

$\mathrm{H}_{\mathrm{O} 1}$ : Student acquisition of employability skills is not a function of gender.

$\mathrm{H}_{\mathrm{O} 2}$ : Student acquisition of employability skills is not a function of industrial training.

$\mathrm{H}_{\mathrm{O} 3}$ : There is no correlation between work experience and the students' employability skills.

$\mathrm{H}_{\mathrm{O} 4}$ : There is no correlation between student acquisition of employability skills and their involvement in extracurricular activities.

$\mathrm{H}_{\mathrm{O} 5}$ : There is no correlation between students' employability skills and their leadership position in the student organizations.

$\mathrm{H}_{\mathrm{O} 6}$ : There is no correlation between participation in career development activities and students' employability skills.

$\mathrm{H}_{\mathrm{O} 7}$ : There is no correlation between self-concept and level of student employability skills.

\section{Method}

\subsection{Participants}

The target population of the study was "Form five" students $(\mathrm{N}=521)$ in selected Malaysian technical secondary schools in the state of Sabah. A total of 239 students from six vocational courses were selected to participate in the study. Of the 239 students selected, 214 students $(90 \%)$ returned the questionnaires.

\subsection{Measures}

Students' employability skills were measured using a 40-item instrument initially developed by the U.S. Secretary's Commission on Achieving Necessary Skills (SCANS). In Malaysia, the SCANS instrument has been used in studies by Bakar and Hanafi (2007), Kazilan et al. (2009), Hanafi (2007), Sharifah (2008), and Rohana (2010). It consists of seven aspects: basic skills, thinking skills, resource management skills, interpersonal skills, system and technology skills, and personal qualities. We asked students to rank how much of those skills they felt they possessed. Students answered the questions using a 5-point Likert scale, where "1" was "I do not possess this skill" and "5" was "I have a lot of this skill". The reliability estimates of each construct ranged between 0.84 and 0.96 , and reliability estimate for the complete study was 0.95 .

\subsection{Procedure}

Questionnaires were administered by the researchers. Prior to students completing the questionnaire, a brief presentation of the study was made. Students were informed of the purpose of the study and were requested to answer the questionnaire given to them. Data were collected in class during school hours under the supervision of a senior TVET teacher.

\section{Results}

The participants consisted of $29.4 \%$ male students and $70.6 \%$ female students $(n=214)$. Their self-concept-that is, their believes of their own abilities and knowledge in comparison to others-as measured using Rosenberg's self-esteem scale $(1965)$ was about moderate $(\mathrm{M}=3.75, \mathrm{SD} .=0.48)$. Almost one-third of them participated in industrial training $(62 \%)$ and almost all of them participated in extracurricular activities with many of them holding some form of leadership positions such as chairman, treasurer, and secretary. All of them had exposure to some form of career development activities, such as visiting higher learning institutions, attending a career talk, or attending a career fair. Almost all students who participated planned to continue their education once they graduated from high school (91.1\%).

Vocational students' employability skills were moderate, with an overall mean of $3.81(\mathrm{SD}=0.34)$. Students had high mean scores in only two aspects: personal qualities $(\mathrm{M}=4: 04, \mathrm{SD}=0.43)$ and interpersonal skills $(\mathrm{M}=$ $4.01, \mathrm{SD}=0.47)$. The other five aspects of employability skills were moderate: resource skills $(\mathrm{M}=3.74, \mathrm{SD}=$ $0.45)$, basic skills $(\mathrm{M}=3.73, \mathrm{SD}=0.46)$, thinking skills $(\mathrm{M}=3.72, \mathrm{SD}=0.42)$, information skills $(\mathrm{M}=3.68, \mathrm{SD}$ $=0.54)$ and systems and technology skills $(\mathrm{M}=3.53, \mathrm{SD}=0.58)$. 
Table 1. Mean scores and standard deviations of students' employability skills $(n=214)$

\begin{tabular}{lll}
\hline Skills & Mean & Standard deviations \\
\hline Basic skills & 3.73 & .46 \\
Thinking skills & 3.72 & .42 \\
Resource management skills & 3.74 & .45 \\
Informational skills & 3.68 & .54 \\
Interpersonal skills & 4.01 & .47 \\
Systems and technology skills & 3.53 & .58 \\
Personal quality & 4.04 & .43 \\
Overall employability skills & 3.81 & .34 \\
\hline
\end{tabular}

Significant correlations were found with gender $\left(\mathrm{r}_{\mathrm{pb}}=-.172, p=.012\right)$, industrial training $\left(\mathrm{r}_{\mathrm{pb}}=.137, p=.046\right)$, involvement in extracurricular activities $(\mathrm{r}=.177, p=.010)$, participation in career activities $(\mathrm{r}=.218, p=.001)$ and self-concept $(\mathrm{r}=.429, p=.000)$. Based on these results, five of our seven hypotheses $\left(\mathrm{H}_{\mathrm{O} 1}, \mathrm{H}_{\mathrm{O} 2}, \mathrm{H}_{\mathrm{O} 4}, \mathrm{H}_{\mathrm{O} 6}\right.$, and $\mathrm{H}_{\mathrm{O} 7}$ ) are rejected. Two hypotheses, $\mathrm{H}_{\mathrm{O} 3}$ and $\mathrm{H}_{\mathrm{O} 5}$ are accepted: there was no significant correlation between students' employability skills with work experience and leadership position in a student's organization.

Table 2. Correlations between employability skills and selected variables $(\mathrm{n}=214)$

\begin{tabular}{lcccccc}
\hline & Employability & Gender & $\begin{array}{c}\text { Industrial } \\
\text { training }\end{array}$ & $\begin{array}{c}\text { Other working } \\
\text { experiences }\end{array}$ & $\begin{array}{c}\text { Participation in } \\
\text { Career activities }\end{array}$ & Self-concept \\
\hline Employability & 1.00 & $-.172^{*}$ & $.137^{*}$ & -.110 & $.218^{* *}$ & $.429^{* *}$ \\
Gender & & 1.00 & -.024 & .093 & -.116 & -.069 \\
Industrial Training & & & 1.00 & $.152^{*}$ & $-.317^{* *}$ & .060 \\
Other working experiences & & & 1.00 & $-.174^{*}$ & -.099 \\
Participation in Career & & & & & 1.00 & .127 \\
Activities & & & & & 1.00 \\
Self-concept & & & & &
\end{tabular}

*Significant correlation at level 0.05 .

**Significant correlation at level 0.01 .

Table 3. Correlation between employability skills, extra-curriculum involvement, and leadership positions $(\mathrm{n}=$ 214)

Employability Extracurricular involvement Leadership position

\begin{tabular}{llll}
\hline Employability & 1.00 & $.177^{* *}$ & 0.034
\end{tabular}

Extracurricular involvement

1.00

$0.320^{* *}$

Leadership position in extracurricular

1.00

Spearman's Rho.

**Significant correlation at level 0.01 (2-tailed).

The third objective of the study was to determine the factors that may influence students' acquisition of employability skills. A multiple regression analysis was performed to determine these factors. Three variables (self-concept, career exposure, and industrial training experience) were regressed; a total of $23 \%$ of the variance in 
the dependent variable (employability skills) can be explained by these three variables. Self-concept was found to contribute $18 \%$ of the variance, $2.7 \%$ of the variance was contributed by career exposure, and $3.1 \%$ of the variance was contributed by industrial training experience. Two other variables (gender and work experience) were excluded, as neither contributed to the variance.

We also ranked the importance of the variables based on beta coefficient. The highest beta coefficient value is shown by self-concept $(0.39)$ and it is the most powerful variable explaining the level of employability skills of the students. Beta coefficient for career exposure was the second highest $(0.23)$, followed by industrial training $(0.19)$.

Table 4. Summary of multiple regression analysis of selected factors on vocational students' employability skills $(\mathrm{n}=214)$

\begin{tabular}{lcccccc}
\hline Variables & $B$ & Std Error & Beta & $t$ & $p$ \\
\cline { 2 - 7 } Constants & 2.39 & .18 & & 13.6 & .000 \\
Self-concept & .27 & .05 & .39 & 6.4 & .000 \\
Career exposure & .37 & .11 & .23 & 3.5 & .000 \\
$\mathrm{R}^{2}=.242$, Adjusted $\mathrm{R}^{2}=.231 ; F(3,210)=22.297, p=.000$. & & &
\end{tabular}

\section{Discussion}

The findings show that the employability skills of vocational secondary school students are moderately high (M $=3.81, \mathrm{SD}=0.34)$. This is similar to findings reported by Fitrisehara, Ramlah, and Rahim (2009). Their study involving 436 final year students at 13 MARA Vocational Institutes showed that the level of student employability skills was moderate $(\mathrm{M}=3.86, \mathrm{SD}=0.36)$. A study by Rohana (2010) using 393 vocational agriculture students also showed that students' employability skills were moderate, but the scores were lower (Mean 3.62, SD. $=0.43$ ) than the current score. Bakar and Hanafi (2007) used 162 technical education students and found that their employability skills were slightly higher $(\mathrm{Mean}=3.8, \mathrm{SD} .=0.55)$ than those obtained by Rohana and almost similar with the result of the present study. Another study by Omar, Bakar, and Rashid (2012) using community college students also confirmed the moderate findings in their sample (Mean $=3.63$, SD. $=$ 0.47). Based on these studies, we can say that employability skills of Malaysian vocational and technical students were moderate to moderately high.

The development of employability skills among students is important for the future of the nation. As a result of new development in the world of work, one can't remain static in one specific organization. People move from one organization to another based on their employability skills. Borrowing the concept of protean career, where one drives his or her career and invents his or her own career over time, the need for employability skills is much stronger and more significant.

Undeniably, the development of employability skills in secondary schools throughout Malaysia is a long process. This development may also take place through extracurricular activities such as sports, clubs, and associations. These activities can help students develop leadership, critical thinking, and teamwork abilities. Chan and Murphy (2010) found that key skills cannot be developed or learned by reading books alone. Knowledge of the key skills should be strengthened through instruction and demonstrations, and by providing opportunities for students to practice.

The present study found that industrial training experience related to the acquisition of employability skills. This finding contradicts those of Omar et al. (2012) who found that industrial training did not necessarily helps students acquire soft skills, though it did helps students increase their technical skills. However, finding by C. Paisey and N. Paisey (2010) shows that experience gained through work placement successfully develops a range of transferable personal skills. Participation in career development activities and a positive self-concept significantly predicted the students' level of employability skills. Exposure and experiences in the working world has a key role in preparing young people for adult world (Chandler, Ringsell, \& Lindop, 2007) and also will help students to make a decision whether to continue schooling or not (Onstenk \& Blokhuis, 2007). Close cooperation between the school, students and employers is essential to enhance employability skills.

It is important for a school to create an environment that is conducive to creating a positive self-concept in students. This present study showed that those with a positive self-concept have high employability skills. In fact 
it is the main predictor, at least for this particular study, of employability acquisition among students.

Teachers who organize the placement of students have stated that this is the right time to encourage students to think, to use their initiative and to be responsible in the new environment. From this experience, students can become highly motivated and improve their performance when returning to school.

\section{Implications of Research}

Overall, this study illustrates that students' employability skills are at average level. Because these skills are vital for their future thus, it has to be improved. Thus, the implementation and development of employability skills in the vocational curriculum in secondary technical schools should be widely practiced.

The findings also show that factors such as self-concept, curriculum, and career exposure are associated with employability skills. Thus, the public, educators, and parents need to realize the importance of these variables that can bolster the performance of students as they enter the workforce.

However, there are also other factors that may contribute to the formation of students' employability skills. Therefore, educational institutions must take certain steps such as reviewing, planning, and implementing strategies for improving and developing the employability skills of their students.

\section{Recommendations}

The Ministry of Education in Malaysia and TVED are working hard on employability issues. The quality of the education system can be evaluated based on students' success in getting jobs immediately after completing school or after having had an opportunity to pursue higher education or training. Therefore, our suggestions target stakeholders such as the Ministry of Education, TVED, school administrators, educators, and industries.

Some schools lack the necessary funds to implement "industrial training" programs, thus the Ministry of Education should seek to provide more funding or incentives for such programs. In addition, the Ministry should adapt the employability skills development module for Institutions of Higher Education, which was launched on August 22, 2006 by the Minister of Higher Education, and should introduce this module at the secondary school level.

There is a need for the TVED, the Ministry of Education, and industries to work together to create innovative policies to uphold technical and vocational education. Voluntary organizations either within or outside the country that are willing to offer places and facilities for students to develop their employability skills are very much needed. Therefore, parties must work together to enable youth and students to receive training or skills relevant to industrial needs. Certification for such programs should be provided, as has long been the practice in other countries including the US and Australia.

Schools should create a unit or team of professionals to support the teaching of employability skills. This unit could organize and manage the activities to provide students with employability skills, such as industrial training, in a more systematic way. The unit should also be responsible for mediation in bridging the relationship between the student and the industry or employer in the local area. Curriculums for teaching and learning will become more attractive if a special session or semester is held for students to conduct practical training. Teachers and educators should create activities and a learning environment that prepares students for the real working world. This step is important to promote a positive self-concept in students in order to produce world-class human capital.

Finally, corporations and industry leaders, as labor users, must work together with the vocational secondary schools to identify necessary training skills. Through this collaboration, vocational education programs will always be relevant and will develop in parallel with industry's needs. We hope that more research can be conducted in the future, such as a study to identify the application of employability skills in each vocational subject.

\section{Conclusion}

From this study it was found that vocational students in Malaysia had a moderately high level of employability skills, which was influenced by students' self-perception, their level of industrial training, and their participation in career development activities. Therefore, the important factors to be highlighted within the school environment include the formation of positive self-concept, involvement in extracurricular activities and the engagement of students in related industries.

The formation of a professional body to coordinate the implementation of employability skills regarding teaching and learning activities inside and outside the classroom should be widely practiced. This includes reviewing the needs for a portfolio. A comprehensive effort to promote the still average employability skills 
elements should be carried out in all vocational secondary schools to prepare the students for the world of work. Further studies of an experimental nature to investigate the effects of industrial training and other school activities should be carried out in vocational secondary schools to gain a clear understanding about what is needed ahead. It would be beneficial to conduct further study concerning the roles and contributions of industrial and business sectors to the development of employability skills among secondary vocational school students.

\section{References}

Ahmad-Tajudin, J. (2009). Vocational and Skills Teachers Professionalism Development. Technical and Vocational Education Division, Ministry of Education Malaysia, Putrajaya.

Alston, A. J., Cromartie, D., Wakefield, D., \& English, C. W. (2009). The importance of employability skills as perceived by the employers of United States' land-grant college and university graduates. Journal of Southern Agricultural Education Research, 59, 56-69.

Bakar, A. R., \& Hanapi, I. (2007). Assessing employability skills of technical-vocational students in Malaysia. Journal of Social Science, 3(4), 202-207. http://dx.doi.org/10.3844/jssp.2007.202.207

Barnett, R. (2006). Graduate attributes in an age of uncertainty. In P. Hager, \& S. Holland (Eds.), Graduate Attributes, Learning and Employability, 6, 49-65. http://dx.doi.org/10.1007/1-4020-5342-8_3

Becker, R. A. (2003). Wisconsin Work-Based Learning Guide. Wisconsin Department of Public Instruction, Madison, Wisconsin.

Carbery, R., \& Garavan, N. T. (2005). Organizational restructuring and downsizing: Issues related to learning, training and employability of survivors. Journal of European Industrial Training, 29(6), 488-508. http://dx.doi.org/10.1108/03090590510610272

Chan, C. K. Y., \& Murphy, M. (2010). Active-based key-skills learning in engineering curriculum to improve student engagement. In M. Iskander, V. Kapila, \& M. A. Karim (Eds.), Technological developments in education and automation (pp. 79-84). http://dx.doi.org/10.1007/978-90-481-3656-8_16

Chandler, N., Ringsell, L., \& Lindop, E. (2007). Time Well Spent: Embedding Employability in Work Experience. Department for Education and Skills, UK.

Crossman, J. E., \& Clarke, M. (2009). International experience and graduate employability: Stakeholder perceptions on the connection. Higher Education, 59(5), 599-613. http://dx.doi.org/10.1007/s10734-009-9268-z

Cushnahan, M. (2009). Beyond Mayer: Learning from delivering and assessing generic employability competencies. NCVER's 'No Frills' Conference, NCVER, Adelaide.

Department of Statistics Malaysia. (2009). Labour Force Survey Report. Department of Statistics Malaysia, Putrajaya.

Fitrisehara, K., Ramlah, H., \& Bakar, A. R. (2009). Employability skills among the students of technical and vocational training centers in Malaysia. European Journal of Social Sciences, 9(1), 147-160.

Government of Malaysia. (2010). Tenth Malaysia Plan: Chapter 5: Developing and Retaining World Class Talent. Putrajaya: The Economic Planning Unit.

Hager, P., \& Holland, S. (2006). Graduate Attributes, Learning and Employability. Springer, Dordrecht.

Hanafi, I. (2007). Analisis Sistem Pendidikan dan Latihan Teknikal-Vokasional di German-Malaysian Institute, Malaysia (Unpublished doctoral thesis, Universiti Putra Malaysia, Serdang, Selangor).

Lorraine, D. P., \& Sewell, P. (2007). The key to employability: Developing a practical model of graduate employability. Education + Training, 49(4), 277-289. http://dx.doi.org/10.1108/00400910710754435

Maclean, R., \& Ordonez, V. (2007). Work, skills development for employability and education for sustainable $\begin{array}{lllll}\text { development. Educational Research Policy } & \text { Practice, } & 6, & 123-140 .\end{array}$ http://dx.doi.org/10.1007/s10671-007-9017-y

Merriam, S. B., Courtenay, B. C., \& Cervero, R. M. (2006). Global Issues and Adult Education: Perspectives from Latin America, Southern Africa, and the United States. Jossey-Bass Publishers, San Francisco.

Ministry of Education. (2007). Technical dan Vocational Curriculum Development. Putrajaya: Technical Education Department.

Mission 2020. (2006). Final Step Stage. Limkokwing University of Creative Technology, Cyberjaya. 
National Centre for Vocational Education Research (Australia). (2003). Defining generic skills: At a glance. Adelaide: NCVER. Retrieved from http://www.ncver.edu.au/research/proj/nr2102b.pdf

National Higher Education Research Institute. (2003). Unemployment studies among graduates: Final report. Minden, Pulau Pinang: USM.

Omar, M. K., Bakar, A. R., \& Rashid, A. (2012). Employability skills acquisition among Malaysian community college students. Journal of Social Science, 8(3), 472-478. http://dx.doi.org/10.3844/jssp.2012.472.478

Onstenk, J., \& Blokhuis, F. (2007). Apprenticeship in The Netherlands: Connecting school-and work-based learning. Education + Training, 49(6), 489-499. http://dx.doi.org/10.1108/00400910710819136

Paisey, C., \& Paisey, N. J. (2010). Developing skills via work placement in accounting: Students and employers views. Account Forum, 34, 89-108. http://dx.doi.org/10.1016/j.accfor.209.06.001

Pemandu. (2012). Economic Transformation Plan Annual Report 2012. Prime Minister's Department: Putra Jaya, Malaysia.

Rabey, G. (2008). On entering the workforce. Industrial and Commercial Training, 40(5), 266-269. http://dx.doi.org/10.1108/00197850810886513

Rohana, A. R. (2010). Minat Kerjaya, Efikasi Kendiri Keputusan Kerjaya, Kemahiran Employability, dan Pilihan Kerjaya Pelajar Pertanian di Semenanjung Malaysia (Unpublished doctoral thesis, Universiti Putra Malaysia, Serdang, Selangor).

Secretary's Commission on Achieving Necessary Skills. (1991). What Work Requires of Schools. A SCANS Report for America 2000. U.S. Department of Labor, Washington, DC. ED332054.

Sharifah, K. S. S. (2008). Participtaion of Vocational Trainees in a Supervised Work Experience and the Acquistion of Employability Skills (Unpublished doctoral thesis, Universiti Putra Malaysia, Serdang, Selangor).

Smith, P. J., Dalton, J., \& Dolheguy, R. (2004). Student experiences of work placement in school-based vocational programs. Education + Training, 46(5), 262-268. http://dx.doi.org/10.1108/00400910410549841

Technical and Vocational Education Division and Technical Secondary Schools. (2010). Image of Excellece. Kuala Lumpur: Book Pro Publishing Services.

Tin, S. T., Suhaida, A. K., Nor-Hayati, H. A., \& Zakaria, A. R. (2009). Creativity Level of Vocational Students. In Z. A. Norhasni, A. K. Suhaida, \& K. Arasinah (Eds.), Strategies on Empowering Technical and Vocational Education (pp. 40-54). University Putera Malaysia Publisher, Serdang.

\section{Copyrights}

Copyright for this article is retained by the author(s), with first publication rights granted to the journal.

This is an open-access article distributed under the terms and conditions of the Creative Commons Attribution license (http://creativecommons.org/licenses/by/3.0/). 